\title{
A Comment on Empirical Estimation of Patterns of Shocks Utilizing the VAR Methodology on Developing Countries
}

\author{
Nephil Matangi Maskay \\ College of Wooster
}

What is a country's optimal choice of an exchange rate regime? One avenue which has gained prominence is the O ptimum Currency Area criteria of pattems of shocks which suggests that a flexible exchange rate may be less costly for regions who face asymmetric shocks, since they are forced to have conflicting policy responses, and vice versa. ${ }^{1}$ While there are a number of methodologies to calculate the pattems of shocks, the VAR methodology, which results from a technique introduced in Bayoumi and Eichengreen $\langle[1992,1994]$; B \& E from now on〉, may be at present one of the most popular. In the estimation of their model the authors have introduced some "over-identifying conditions"2 (called OIC from now on) which confirm the validity of their decomposition.

\footnotetext{
* Correspondence Address: D epartment of E conomics, College of Wooster, W oooster,
} 
While these conditions seem to be met for developed countries, ${ }^{3}$ it does not seem so for developing economies. I comment on a recent article by Horvath and Grabowski 〈[ 1997]; HG from now on〉 who look at the prospect of African integration although ignoring the OIC.

Is the OIC important? Although it does not seem to significantly alter the conclusion for the question of African integration, I would argue that its failure indicates that something is wrong with the VAR decomposition. One problem may deal with the quality of data where developed countries have, on average, better quality data than developing countries 〈Summers and Heston [1993]). Another potentially serious problem is that the model may not capture reality. This is seen in B\&E's [1995] explanation for the perverse price response in Bordo [1993] as the close connection of prices in a commodity standard. Likewise, it may be that the VAR technique does not differentiate between nominal and real demand shocks 〈N ueman [1993]〉 where for $\mathrm{Nepal}$ and India there is the presence of temporary real shocks from agriculture 〈Bajracharya and M askay [1998]〉. While the explanations of why developing countries fail the OIC are many, overlooking these results, ignores some valuable information in the dynamics of developing countries.

However $\mathrm{HG}^{4}$ ignore the OIC when doing a VAR analysis, such as $B \& E$, and conclude that the scope for integration in Africa is limited. This contrasts with Bayoumi and Ostry 〈[1995]; B\&O from now on〉, who look at Africa during roughly the same period (i.e. 1964-1993 vs. 1960-1992), and comment that :

"Unfortunately...the results from the vector autoregression did not satisfy the expected "over-identifying restrictions" on price responses...to confirm the validity of [the] decomposition.." 'from B\&O [1995], p. 14〉

$B \& O$ then went on to use a simpler estimation methodology $y^{5}$ to reach 
roughly the same conclusion as $\mathrm{HG}$ based on the pattern of real shocks.

While both results are similar, the model implied by HG is inconsistent with the standard aggregate supply (AS) - aggregate demand (AD) model of $B \& E$ (i.e. that the $A D$ curve is down ward sloping while the short run $A S$ curve is upward sloping and the long run AS curve is vertical). That is, the failure of the OIC suggests, from the impulse response function of prices $\langle$ as with Bordo [1993] and M askay [1998]), that a positively sloped AD curve, rather than a negatively sloped $A D$ curve, exists. In other words there is a conflict between the estimated model and the model described by the data. Thus, due to this inconsistency, any conclusion based upon these results would not be valid. ${ }^{6}$

To conclude, the failure by HG to examine the OIC brings into question the validity of their results. M ore generally, the dichotomy of accepting and rejecting the OIC between developed and developing countries (suggested from the above, albeit limited, samples) would seem to imply that the VAR is too sophisticated a technique for the quality of data to be found in developing economies.

\section{References}

Aghevli, Bijan B., M ohsin S. Khan and Peter J. M ontiel [1991], "Exchange Rate Policy in Developing Countries: Some Analytical Issues," IMF Occasional Papers No. 78, March.

6. While this information suggests that application of a VAR analysis is not valid, its failure convey information which, through further examination, may result in broader insight. Consider the case of $\mathrm{Nepal}$ and India which failed the OIC 〈M askay [1998]〉. The results from a simpler estimation strategy, $B \& O$, suggest that neither country faced symmetric patterns of shocks. This can be traced to the developing, agricultur- 
Arnon, Arie and Avia Spivak [1996], "M onetary Integration between the Israeli, Jordanian and Palestinian Economies," Wel twi rtshaftliches Archiv 132(2).; pp. 259-277.

Bajracharya, Bhuban Barja and Nephil M atangi M askay [1998], "The Aggregate Supply Response for Nepalese Agriculture for the Period 1967/ 68-1994/95" forthcoming in The Journal of Development and Administrative Studies.

Bayoumi, Tamim [1992], "The Effects of the ERM on Participating Economics" International M onetary F und Staff Paper, 39, J une; pp. 330-356.

Bayoumi, Tamim and Barry Eichengreen [1992], "Shocking Aspects of European M onetary Unification," NB ER Working Paper N o. 3949, J anuary.

Bayoumi, Tamim and Barry Eichengreen [1994], "One Money or Many? Analyzing the Prospects for M onetary Unification in Various Parts of the World," Princeton Studies in International Finance, No. 76, September.

Bayoumi, Tamim and Barry Eichengreen [1995], "The Stability of the Gold Standard and the Evolution of the International M onetary System" IM F Working Papers, September.

Bayoumi, Tamim and Jonathan D. Ostry [1995], "M acroeconomic Shocks and Trade Flows within Sub-Saharan Africa: Implications for O ptimum Currency Arrangements," IM F Working Paper, December.

Bordo, M ichael [1993] "The Gold Standard, B retton Woods and other M onetary Regimes: A Historical Perspective" Review: The Federal Reserve Bank of St. Louis 75, N o. 2.

Horvath, Julius and Richard Grabowski [1997], "Prospects of African Integration in Light of the Theory of Optimum Currency Areas," Journal of Economic Integration, 12(1), M arch; pp. 1-25.

M askay, Nephil M atangi [1998a], "A Cautionary N ote in Using Patterns of 
tion of Currency Unions, Great B ritain: Cambridge University Press.

Neumann, M anfred J. M. "Commentary," Review: The Federal Reserve B ank of St. Louis 75, N o. 2; pp. 192-199.

Pilbeam, Keith [1992], International Finance, Hong Kong: M acmillan Press Ltd. 